\title{
PEMODELAN PUMPING TEST SEBAGAI DASAR PERHITUNGAN DEWATERING PADA PROYEK DI SUDIRMAN
}

\author{
Aldo Lorenza ${ }^{1}$, Gregorius Sandjaja Sentosa ${ }^{2}$ dan Ali Iskandar ${ }^{3}$ \\ 1Program Studi Sarjana Teknik Sipil, Universitas Tarumanagara, Jl.Letjen S. Parman No.1 Jakarta \\ Email: lorenzaaldo@gmail.com \\ 2 Program Studi Sarjana Teknik Sipil, Universitas Tarumanagara, Jl.Letjen S. Parman No.1 Jakarta \\ Email: gregoriuss@ft.untar.ac.id \\ 3Program Studi Sarjana Teknik Sipil, Universitas Tarumanagara, Jl.Letjen S. Parman No.1 Jakarta \\ Email: ali.iskandar1999@gmail.com
}

\begin{abstract}
ABSTRAK
Pesatnya laju pembangunan dan mahalnya harga lahan mendorong pembangunan secara vertikal baik ke atas ataupun ke bawah. Pembangunan secara vertikal ke bawah atau pembangunan basement memerlukan tahap konstruksi galian dalam yang sering ditemui masalah seperti muka air tanah yang berada lebih tinggi dari galian tersebut sehingga dapat mengakibatkan pekerjaan dalam galian serta kestabilan dari galian tersebut menjadi terganggu. Untuk menjaga supaya muka air tanah berada dibawah galian yang direncanakan, maka digunakan suatu metode drainase dengan pemompaan yang disebut sistem dewatering. Pada salah satu proyek di Sudirman, Jakarta, dilakukan pembangunan basement sedalam 7 lantai dengan kedalaman galian 29 meter yang akan melaksanakan pekerjaan dewatering. Dalam merencanakan dewatering diperlukan beberapa hidrogeologi parameter yang dapat ditentukan dengan berbagai macam metode. Metode yang akan digunakan pada proyek ini adalah pumping test. Berdasarkan hasil pumping test di lapangan, pola penurunan muka air tanahnya akan dimodelkan dengan menggunakan program berbasis metode elemen hingga (2D) dan metode beda hingga (3D) untuk memperoleh parameter dalam merencanakan dewatering dengan program berbasis metode beda hingga (3D). Berdasarkan hasil pemodelan pumping test, didapatkan nilai koefisien permeabilitas yang menjadi penentu faktor penurunan muka air tanah. Nilai koefisien permeabilitas tersebut akan menjadi dasar dalam perhitungan dewatering sehingga diperoleh pompa yang dibutuhkan pada proyek tersebut sebanyak 4 buah pompa dengan kapasitas masing-masing pompa sebesar $352 \mathrm{~m}^{3} /$ hari.
\end{abstract}

Kata kunci: basement, muka air tanah, pumping test, dewatering, koefisien permeabilitas

\section{PENDAHULUAN}

\section{Latar belakang}

Pesatnya laju pembangunan dan semakin tingginya harga lahan mendorong pembangunan dibangun secara vertikal baik ke atas ataupun ke bawah. Pada pembangunan vertikal ke bawah atau pembangunan basement perlu dilakukan tahap konstruksi galian dalam yang sering ditemui masalah yaitu elevasi muka air tanah yang berada di atas elevasi galian rencana. Untuk menjaga supaya muka air tanah berada di bawah galian rencana maka digunakan suatu metode drainase dengan pemompaan yang disebut dewatering.

Sistem dewatering ini akan diterapkan pada salah satu proyek di Sudirman yang akan dibangun basement sedalam 7 lantai dengan kedalaman galian 29 m dikarenakan letak lokasi proyek yang berada ditengah kota dan dekat dengan Kali Krukut sehingga rentan terjadi luapan debit air. Tingginya luapan debit air membuat tinggi muka air tanah di lahan proyek tersebut jauh di atas galian rencana sehingga membuat pelaksanaan pekerjaan basement menjadi lebih sulit.

Dalam merencanakan sistem dewatering diperlukan beberapa hidrogeologi parameter dan untuk mendapatkan parameter-parameter hidrogeologi tersebut dapat dilakukan dengan berbagai macam metode. Namun, pada proyek di Sudirman ini metode yang akan digunakan adalah pumping test. Pentingnya peranan sistem dewatering pada proyek di Sudirman ini yaitu dalam menentukan jumlah dan kapasitas pompa yang akan digunakan nantinya. Maka, penulis akan melakukan pemodelan terhadap tinggi muka air tanah berdasarkan hasil pumping test di lapangan dengan menggunakan program. Hal ini diharapkan dapat menghasilkan parameter yang nantinya akan digunakan dalam 
merencanakan dewatering pada proyek tersebut dengan mengetahui kapasitas dan jumlah pompa yang diperlukan dengan menggunakan bantuan program.

\section{Tujuan penelitian}

Tujuan dari penelitian ini adalah mengetahui parameter yang mengontrol pola penurunan muka air tanah hasil pengujian pumping test, memperoleh kecocokan pola penurunan muka air tanah hasil pengujian pumping test di lapangan dengan hasil pemodelan, mengetahui jumlah dan kapasitas pompa yang dibutuhkan untuk pelaksanaan dewatering pada proyek di Sudirman tersebut.

\section{Aquifer, aquitard, dan aquiclude}

Aquifer merupakan lapisan bawah tanah yang menyimpan air dan dapat mengalirkan air. Menurut Kruseman dan de Ridder (2000), aquifer merupakan unit geologi permeable seperti pasir dan kerikil, tetapi batuan sedimen permeable seperti batu kapur, vulkanik, dan kristal yang retak atau lapuk dapat diklasifikasikan sebagai aquifer juga. Untuk dapat berfungsi sebagai aquifer, suatu batuan haruslah berpori atau berongga yang berhubungan satu sama lain, sehingga dapat menyimpan dan membiarkan air bergerak dari rongga ke rongga.Aquitard adalah lapisan tanah yang cukup permeable untuk dilewati air dalam jumlah yang signifikan jika dilihat dari area yang luas dan periode yang panjang. Clay, loams, dan shales adalah contoh dari lapisan tanah aquitard.Aquiclude adalah lapisan tanah yang kedap air (impermeable) dan tidak dapat dilalui air sama sekali. Salah satu contohnya adalah batuan beku atau batuan metamorf.

\section{Pumping test}

Pumping test merupakan suatu metode uji pemompaan yang sangat sederhana yaitu dengan melakukan pemompaan air dari dalam tanah melalui sumur atau pumping well yang membuat muka air tanah mengalami penurunan. Muka air tanah dan besarnya debit air yang keluar dari pumping well dipantau serta dilakukan pencatatan dari waktu ke waktu, bersama dengan parameter lainnya seperti muka air tanah pada observation well dan jaraknya terhadap pumping well. Data dari hasil uji pemompaan pumping test tersebut kemudian dianalisis untuk mendapatkan parameter-parameter untuk merencanakan dewatering.

Menurut (Cashman, 2013), uji pemompaan pumping test yang direncanakan, dilaksanakan, dan dianalisis dengan benar merupakan metode yang paling dapat diandalkan untuk menentukan parameter permebilitas pada lapisan tanah.

\section{Steady-state flow}

Steady-state flow merupakan suatu aliran fluida dimana kondisi alirannya (kecepatan, tekanan, densitas, dsb) tidak berubah terhadap waktu. Thiem (1906) sebagai orang pertama yang mengembangkan sebuah model matematika untuk sebuah sumur pada sebuah lapisan confined aquifer pada kondisi steady-state flow. Thiem melakukan percobaan dengan melakukan pemompaan dengan memasang lebih dari satu piezometerlobservation well untuk memantau penurunan muka air tanah di sekitar pumping well. Debit pada kondisi steady-state flow dapat diperoleh dari persamaan:

$$
Q=\frac{2 \pi k D(h 2-h 1)}{\ln \left(\frac{r 2}{r 1}\right)}
$$

dengan $\mathrm{Q}=$ debit air $\left(\mathrm{m}^{3} / \mathrm{s}\right), \mathrm{K}=$ konduktivitas hidrolik (m/detik), $\mathrm{D}=$ tebal lapisan aquifer $(\mathrm{m}), \mathrm{r}=$ jarak pumping well $\mathrm{ke}$ observation well $(\mathrm{m})$, dan $\mathrm{h}=$ tinggi muka air tanah dari datum $(\mathrm{m})$.

\section{Dewatering}

Dewatering didefinisikan sebagai sebuah proses untuk memompa dari sumur atau tempat penampungan air yang bertujuan untuk menurunkan muka air tanah. Hal ini bertujuan untuk memungkinkan penggalian dibuat dalam kondisi kering dan stabil di bawah permukaan air tanah.

\section{Metode dewatering}

Dalam pemilihan dan penggunaan metode dewatering harus mempertimbangkan kondisi pada lokasi tersebut. Adapun beberapa metode dalam dewatering sebagai berikut:

\section{Sump Pumping}

Sump pumping merupakan suatu metode dimana air dikumpulkan di bagian yang lebih dalam dari penggalian dan dipompa keluar. Metode sump pumping merupakan suatu metode yang sederhana dan murah, namun metode ini memiliki batasan yaitu digunakan pada tanah yang relatif kasar atau batu pecah. 


\section{Wellpoints}

Wellpoints merupakan suatu metode dimana sumur berdiameter kecil dipasang pada jarak dekat yaitu 1 hingga 3 meter di sekitar penggalian. Pada umumnya metode wellpoints digunakan untuk dewatering parit pipa. Metode wellpoints ini sangat fleksibel dan efektif pada tanah pasir dan berkerikil.

\section{Deepwells}

Deepwells merupakan suatu metode dimana sumur dibor dengan jarak yang lebar yaitu 10 hingga 60 m antar sumur untuk membentuk cincin di sekitar bagian luar penggalian. Submersible pump dipasang disetiap sumur serta drawdown pada metode deepwells hanya dibatasi oleh kedalaman sumur dan stratifikasi tanah.

\section{Eductor Wells}

Eductor wells merupakan metode yang efektif untuk menstabilkan tanah halus dengan mengurangi tekanan air pori. Pada metode Eductor wells sumur dibor di sekitar atau di samping penggalian dengan kapasitas aliran 30 hingga 50 liter / menit per sumur. Drawdown pada metode Eductor wells umumnya terbatas pada 25 hingga $30 \mathrm{~m}$ di bawah elevasi pompa.

\section{Relief Wells}

Relief wells merupakan suatu metode yang digunakan untuk mengurangi tekanan air pori di akuifer terkekang (confined aquifers) atau dalam kondisi tanah berlapis. Air yang mengalir dari relief wells akan dibuang dengan bantuan sump pumping. Pada pelaksanaan relief wells ini juga menggunakan selimut drainase granular dan jaringan drainase yang berfungsi untuk mengarahkan air hasil pemompaan ke bak dan mencegah timbulnya kolam di area galian.

\section{Program berbasis elemen hingga (2D)}

Program berbasis metode elemen hingga (finite element method) dua dimensi ini dapat digunakan untuk merencanakan pondasi, analisis deformasi, pengecekan stabilitas pada tanah, menghitung tegangan yang terjadi pada timbunan, dan lain sebagainya. Finite Element Method (FEM) atau biasa disebut Finite Element Analysis (FEA), adalah prosedur numeris yang dapat dipakai untuk menyelesaikan masalah-masalah dalam bidang rekayasa (engineering). Kondisi tanah di lapangan dapat dimodelkan dalam program berbasis elemen hingga tersebut untuk mengimplementasikan tahapan pelaksanaan konstruksi di lapangan ke dalam pengerjaan program sehingga hasil yang dikeluarkan oleh program ini dapat sedekat mungkin dengan hasil yang terjadi di lapangan. Sehingga respon yang dihasilkan oleh program ini dianggap sebagai cerminan dari kondisi yang terjadi di lapangan.

\section{Program berbasis beda hingga (3D)}

Program berbasis beda hingga ini adalah sebuah program yang mampu memodelkan konseptual aliran air tanah dan pemodelan numerik dengan menggunakan objek data mentah. pemodelan numerik merupakan pemodelan dengan merancang grid model dimaksudkan untuk membantu dalam pemecahan permasalahan air tanah secara lebih sistematis dengan pendekatan matematis. Dalam merekayasa grid model perlu mempertimbangkan faktor seperti jenis atau macam permasalahan yang akan dipecahkan, wujud dari aquifer, ketersediaan data, bentuk dari batas model, serta merencanakan jumlah sel (nodal cell). Dengan mempertimbangkan hal tersebut, rancangan grid model aliran air tanah di daerah model dibuat berdasarkan konsep metode beda hingga (finite difference method).

\section{Equivalent radius $\left(\boldsymbol{r}_{\mathrm{s}}\right)$}

Equivalent radius $\left(\mathrm{r}_{\mathrm{s}}\right.$ ) merupakan jari-jari dari seluruh sumur yang dihubungkan menjadi satu hingga menjadi satu kesatuan sumur yang besar. Equivalent radius $\left(\mathrm{r}_{\mathrm{s}}\right)$ dapat diasumsikan berbentuk persegi atau lingkaran dengan rumus sebagai berikut:

Rumus equivalent radius $\left(\mathrm{r}_{\mathrm{s}}\right)$ dengan bentuk persegi

Rumus equivalent radius $\left(\mathrm{r}_{\mathrm{s}}\right)$ dengan bentuk lingkaran

$$
r_{s}=\sqrt{\frac{a b}{\pi}}
$$

$$
r_{s}=\frac{a+b}{\pi}
$$

dengan $\mathrm{r}_{\mathrm{s}}=$ equivalent radius $(\mathrm{m})$ dan $\mathrm{a}, \mathrm{b}=$ sisi pada setiap bentuk equivalent radius $(\mathrm{m})$. 


\section{Radius of influence $\left(\boldsymbol{R}_{o}\right)$}

Radius of influence $\left(\mathrm{R}_{\mathrm{o}}\right)$ didefinisikan sebagai jarak maksimum dimana drawdown dapat dideteksi. Radius of influence merupakan konsep yang baik dalam situasi equilibrium maupun non-equilibrium.

\section{Kapasitas pompa $\left(\mathbf{Q}_{w}\right)$}

Kapasitas pompa individu dalam dewatering adalah faktor penting dalam mendesain karena dari kapasitas pompa tersebut dapat ditentukan jumlah sumur yang diperlukan untuk melakukan pekerjaan dewatering. Pada muka air lapisan aquifer yang dasarnya tidak jauh di bawah tanah dasar dari penggalian, perancangan dibatasi oleh panjang screen yang tersisa pada kondisi dewatered. Kapasitas pompa dapat ditentukan dengan rumus sebagai berikut:

$$
Q_{w}=24.91 \times h \times r_{w} \times \sqrt{k}
$$

dengan $\mathrm{Q}_{\mathrm{w}}=$ kapasitas pompa (liter/menit), $\mathrm{h}=\operatorname{tinggi}$ muka air dari datum $(\mathrm{m}), \mathrm{r}_{\mathrm{w}}=$ radius minimum $(\mathrm{mm})$, dan $\mathrm{k}=$ konduktivitas hidraulik (m/detik).

\section{METODOLOGI PENELITIAN}

\section{Metode pengumpulan data}

Metode yang digunakan untuk pengumpulan data penelitian ini adalah teknik dokumentasi yaitu pengumpulan data dari proyek. Setelah data berhasil didapatkan, kemudian dilakukan korelasi parameter tanah sehingga diperoleh parameter yang dibutuhkan untuk melakukan pemodelan pumping test yang dicocokan dengan hasil lapangan. Kemudian hasil pemodelan tersebut dijadikan dasar pemodelan dewatering untuk memperhitungkan jumlah pompa dan kapasitas pompa yang diperlukan pada proyek di Sudirman tersebut.

\section{Metode analisis data}

Metode analisis yang digunakan untuk menganalisa data menggunakan program berbasis elemen hingga (2D) dan berbasis beda hingga (3D). Sebelum dilakukannya analisis data, perlu adanya studi literature dengan mencari dasar - dasar teori dan sumber data seperti jurnal, buku referensi untuk mendapatkan rumus-rumus.

\section{ANALISIS DAN PEMBAHASAN}

\section{Kesimpulan parameter}

Berdasarkan hasil uji laboratorium, lapangan, dan hasil korelasi, dapat dianalisis untuk mendapatkan berbagai macam parameter yang akan digunakan untuk melakukan pemodelan. Berikut merupakan kesimpulan parameter yang digunakan untuk pemodelan pumping test dengan program berbasis elemen hingga (2D) dan berbasis beda hingga (3D) yang dapat dilihat pada Tabel 1 dan Tabel 2 sebagai berikut.

Tabel 1. Tabel Kesimpulan parameter tanah

\begin{tabular}{|c|c|c|c|c|c|c|c|c|c|c|}
\hline \multirow{2}{*}{ Kedalaman } & \multirow{2}{*}{ Jenis Tanah } & \multicolumn{7}{|c|}{ Parameter } \\
\cline { 3 - 12 } & & Ysat & Yunsat & $\mathrm{kx}$ & $\mathrm{ky}$ & $\mathrm{Es}$ & $\mathrm{v}$ & $\mathrm{c}^{\prime}$ & $\phi$ & $\psi$ \\
\cline { 3 - 12 } & & $\mathrm{kN} / \mathrm{m}^{3}$ & $\mathrm{kN} / \mathrm{m}^{3}$ & $\mathrm{~m} / \mathrm{hari}$ & $\mathrm{m} / \mathrm{hari}$ & $\mathrm{kN} / \mathrm{m}^{2}$ & - & $\mathrm{kN} / \mathrm{m}^{2}$ & ${ }^{\circ}$ & ${ }^{\circ}$ \\
\hline $0-9 \mathrm{~m}$ & Silty Clay & 19.27 & 18.27 & 0.39 & 0.39 & 50000 & 0.3 & 8.6 & 25 & 0 \\
\hline $9-21 \mathrm{~m}$ & Sandy Silt & 19.15 & 18.15 & 13.97 & 13.97 & 20000 & 0.35 & 26.4 & 32 & 10 \\
\hline $21-41 \mathrm{~m}$ & Silty Clay & 19.03 & 18.03 & 1.11 & 1.11 & 50000 & 0.3 & 24.8 & 25 & 0 \\
\hline $41-52 \mathrm{~m}$ & Sandy Silt & 18.76 & 17.76 & 7.95 & 7.95 & 20000 & 0.35 & 17.4 & 32 & 10 \\
\hline $52-80 \mathrm{~m}$ & Silty Clay & 19.38 & 18.38 & 0.13 & 0.13 & 50000 & 0.3 & 21.8 & 25 & 0 \\
\hline
\end{tabular}

Tabel 2. Kesimpulan parameter pompa pada program berbasis elemen hingga

\begin{tabular}{|c|c|c|}
\hline Well Type & Koordinat Pompa & Debit Pompa (m3/hari/m) \\
\hline Extraction & $(0.3,-39)$ & 671.41 \\
\hline
\end{tabular}




\section{Konduktivitas hidraulik (Thiem's Equilibrium Formula)}

Perhitungan konduktivitas hidraulik menggunakan rumus yang digagas oleh Thiem (1906) pada lapisan aquifer yaitu pada kedalaman 9-21 meter dengan kondisi steady state flow. Perhitungan dengan rumus Thiem tersebut berdasarkan data pumping test lapangan yang dicari nilai permeabilitasnya berdasarkan hubungan antara well yang dapat dilihat pada Tabel 3. Berdasarkan perhitungan dengan rumus tersebut, dapat diketahui nilai permeabilitas setiap hubungan antar pumping well dengan observation well dan juga antar observation well yaitu berkisar antara 4.07 hingga $14.92 \mathrm{~m} /$ hari yang dapat dilihat pada Tabel 4 sebagai berikut.

Tabel 3. Data pumping test lapangan

\begin{tabular}{|l|c|c|c|c|c|c|c|}
\hline & PW2 & OW7 & OW8 & OW9 & OW10 & OW11 & OW12 \\
\hline Jarak dari PW2 (m) & 0 & 2 & 4 & 8 & 16 & 32 & 64 \\
\hline Final GWL (actual) (m) & 30.94 & 14.11 & 13.45 & 12.02 & 12.18 & 9.41 & 10.84 \\
\hline Final GWL (corrected) (m) & 30.94 & 14.11 & 13.45 & 12.02 & 11.63 & 11.23 & 10.84 \\
\hline h (m) & 9.06 & 25.89 & 26.55 & 27.98 & 28.37 & 28.77 & 29.16 \\
\hline kedalaman sumur (m) & 40 & 30 & 30 & 30 & 30 & 30 & 30 \\
\hline
\end{tabular}

Tabel 4. Tabel nilai permeabilitas

\begin{tabular}{|c|c|c|c|c|c|c|c|}
\hline \multicolumn{7}{|c|}{ Konduktivitas Hidraulik (m/hari) } \\
\hline & PW2 & OW7 & OW8 & OW9 & OW10 & OW11 & OW12 \\
\hline PW2 & - & 8.81 & 4.07 & 14.92 & 14.54 & 14.92 & 8.90 \\
\hline OW7 & - & - & 8.81 & 5.57 & 7.04 & 8.08 & 8.90 \\
\hline OW8 & - & - & - & 4.07 & 6.39 & 7.86 & 8.92 \\
\hline OW9 & - & - & - & - & 14.92 & 14.73 & 14.79 \\
\hline OW10 & - & - & - & - & - & 14.54 & 14.73 \\
\hline OW11 & - & - & - & - & - & - & 14.92 \\
\hline OW12 & - & - & - & - & - & - & - \\
\hline
\end{tabular}

\section{Pemodelan pumping test dengan program berbasis elemen hingga (2D)}

Berdasarkan hasil parameter yang sudah ditentukan, akan dimasukkan ke dalam program berbasis elemen hingga (2D) tersebut dengan nilai konduktivitas hidraulik pada lapisan aquifer nya diubah dengan hasil korelasi dan perhitungan dengan rumus Thiem. Hasil pemodelan pumping test dengan program berbasis elemen hingga dapat dilihat pada gambar berikut ini. 


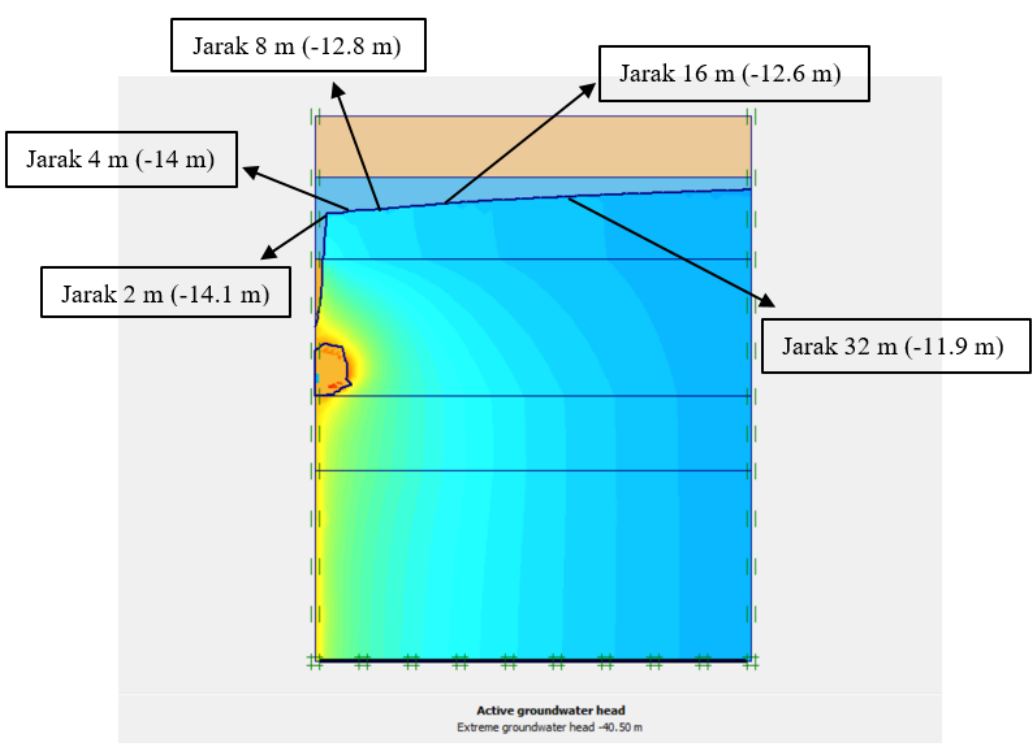

Gambar 1. Hasil Pemodelan Dengan Nilai K Sebesar 13.97 M/Hari (korelasi)

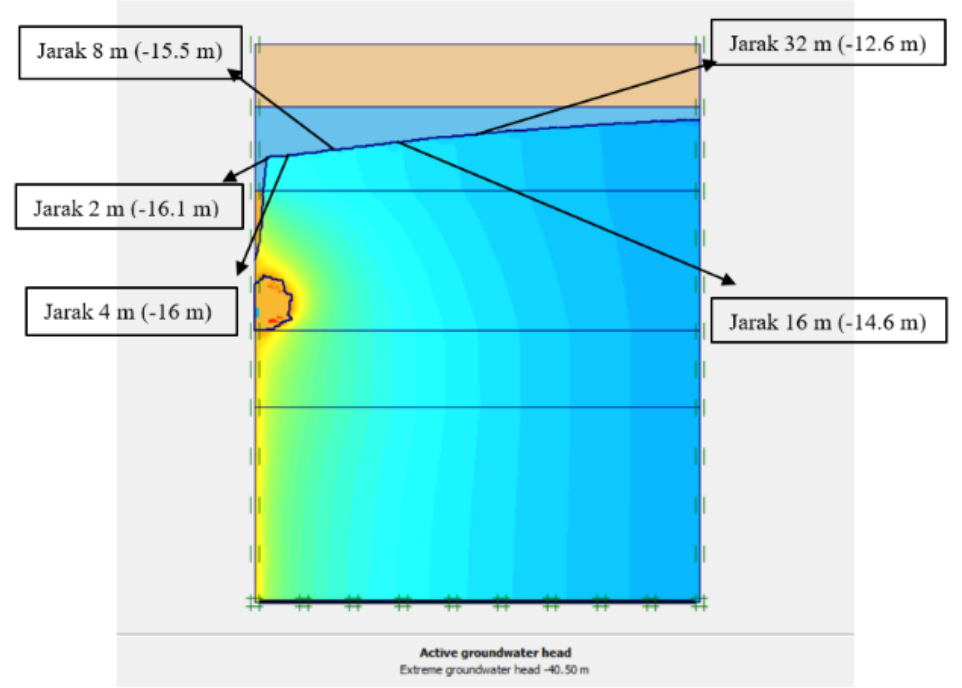

Gambar 2. Hasil Pemodelan Dengan Nilai K Sebesar 4.07 M/Hari (Thiem Min) 


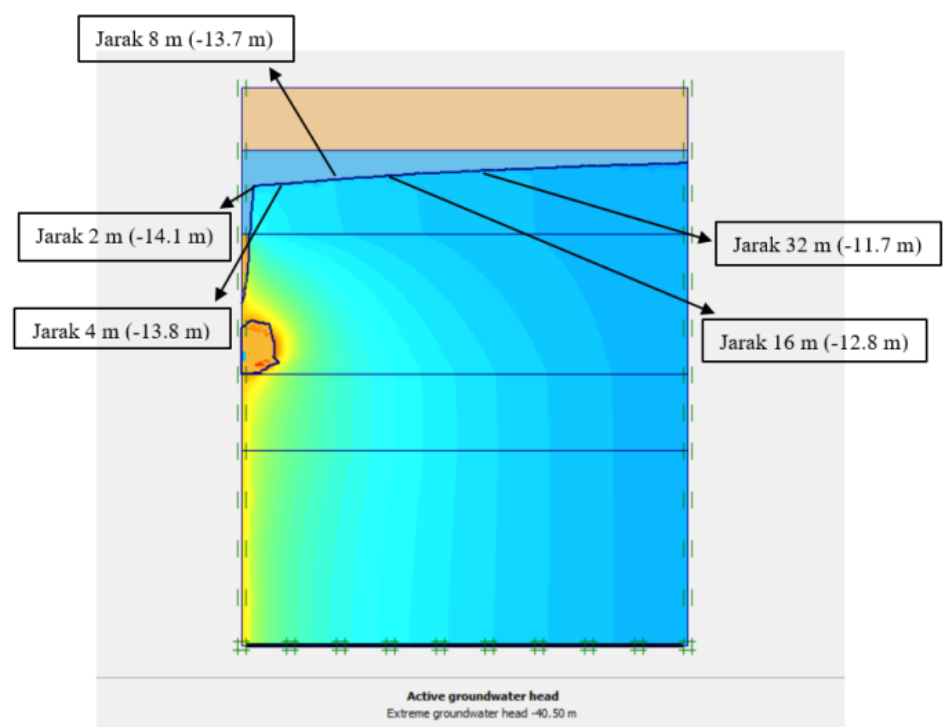

Gambar 3. Hasil Pemodelan Dengan Nilai K Sebesar 14.92 M/Hari (Thiem Max)

\section{Pemodelan pumping test dengan program berbasis beda hingga (3D)}

Selain pemodelan pumping test dengan menggunakan berbasis elemen hingga (2D), selanjutnya pemodelan dilakukan dengan menggunakan program berbasis beda hingga (3D) dengan menggunakan parameter dan perhitungan nilai permeabilitas yang sudah ada. Hasil pemodelan pumping test dengan program berbasis beda hingga dapat dilihat pada gambar berikut ini.

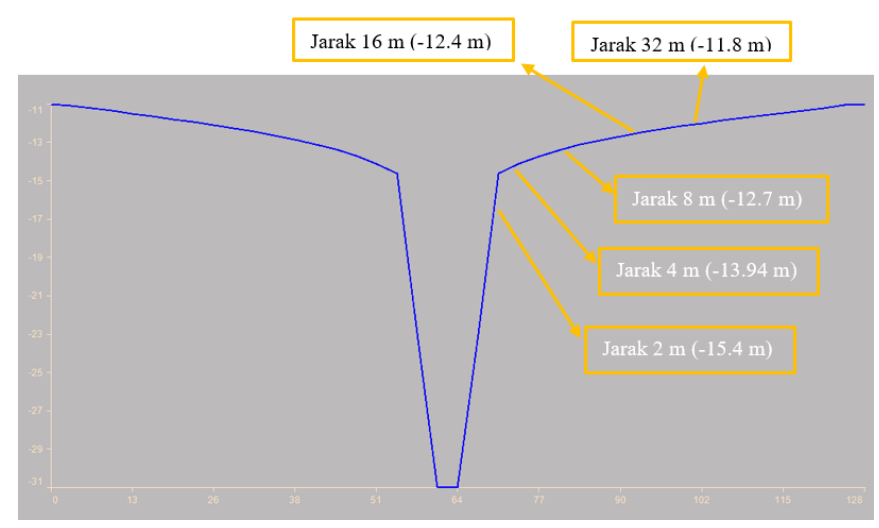

Gambar 4. Hasil pemodelan dengan nilai K sebesar 13.97 m/hari (korelasi)

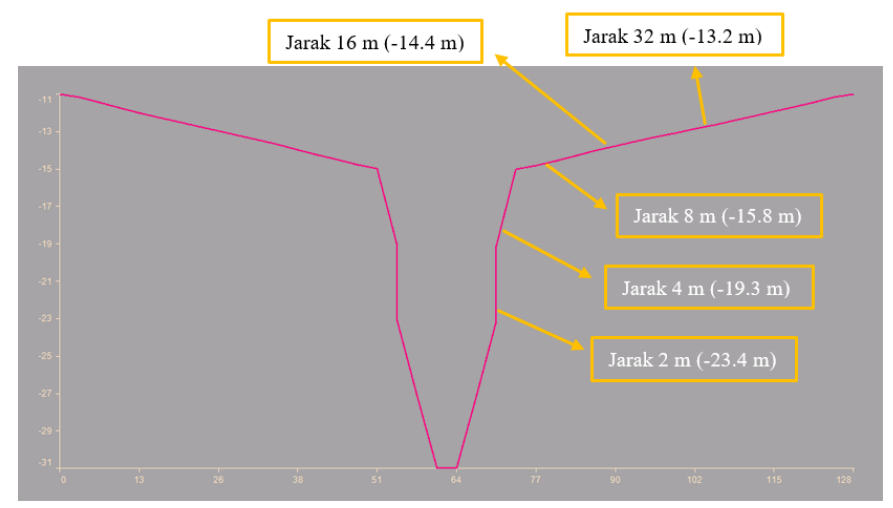

Gambar 5. Hasil pemodelan dengan nilai K sebesar $4.07 \mathrm{~m} / \mathrm{hari}$ (Thiem min) 


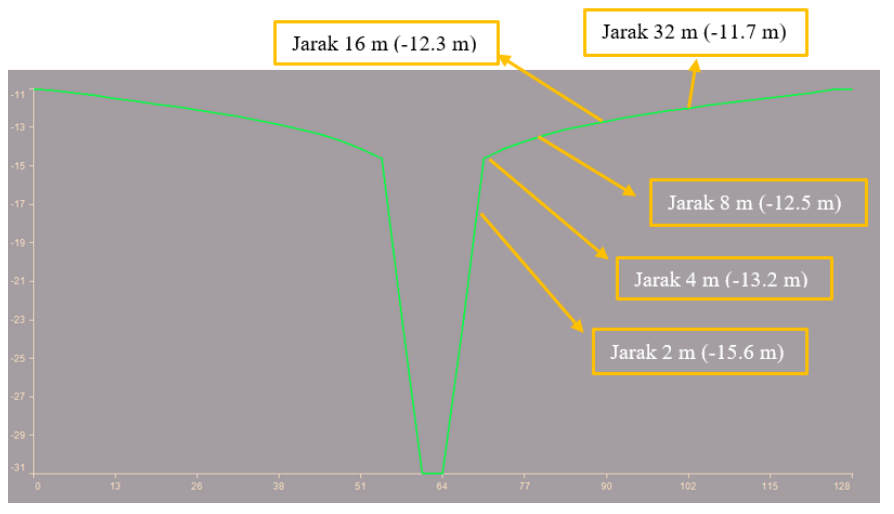

Gambar 6. Hasil pemodelan dengan nilai K sebesar $14.92 \mathrm{~m} /$ hari (Thiem max)

\section{Hasil pemodelan pumping test}

Berdasarkan hasil pemodelan pumping test dengan program berbasis elemen hingga (2D) dan program berbasis beda hingga (3D) di atas, data kesimpulan tersebut dijadikan sebuah grafik pola penurunan muka air tanah sehingga dapat disimpulkan nilai permeabilitas yang cocok dengan pola penurunan muka air tanah hasil pengetesan di lapangan. Hal tersebut dapat dilihat pada gambar berikut ini.

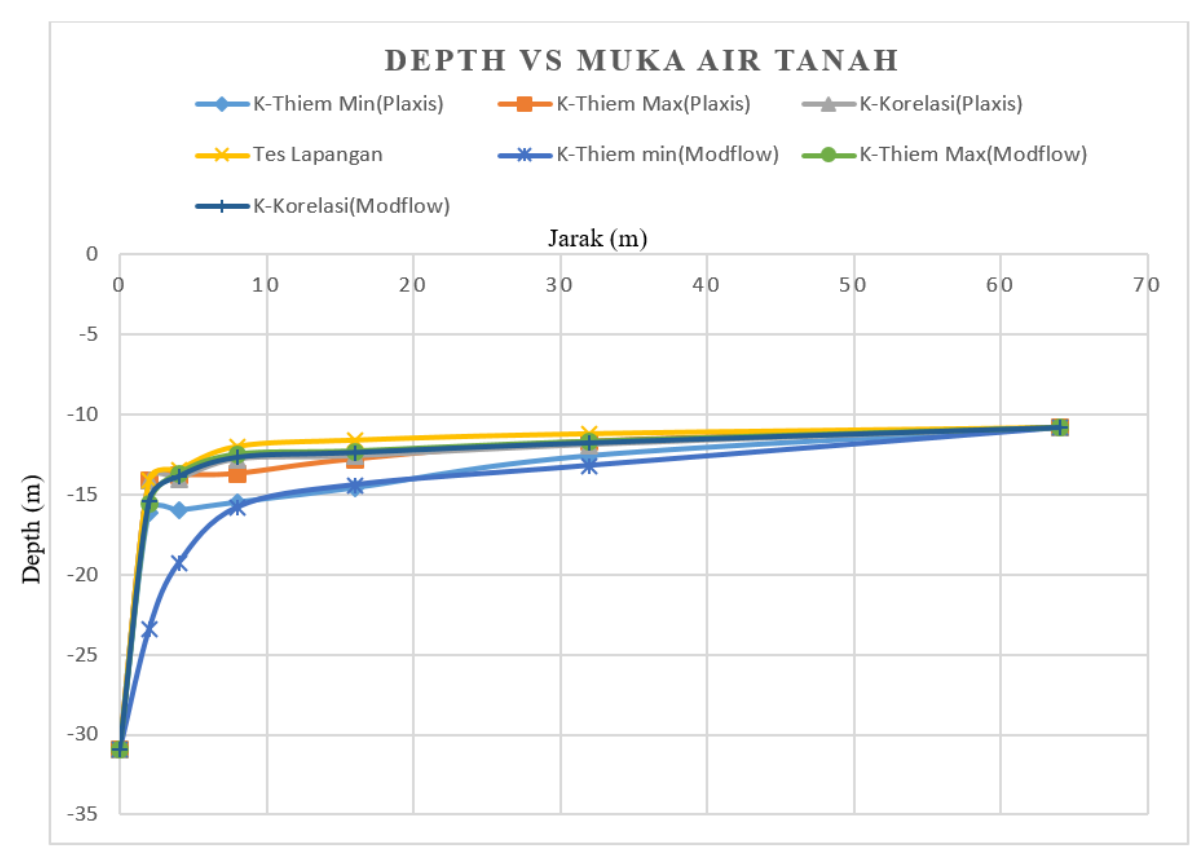

Gambar 7. Perbandingan pola penurunan hasil pengamatan dan pemodelan

Berdasarkan hasil pemodelan pumping test dengan kedua program tersebut didapatkan nilai permeabilitas pada lapisan aquifer yang mendekati dengan hasil pengetesan di lapangan adalah nilai permeabilitas maksimum dengan rumus Thiem Equilibrium Formula $(\mathrm{K}=14.92 \mathrm{~m} / \mathrm{hari})$. Sehingga nilai permeabilitas pada lapisan aquifer tersebut yang akan menjadi parameter untuk pemodelan dewatering. 


\section{Pemodelan dewatering dengan program berbasis beda hingga (3D)}

Pada pemodelan ini, menggunakan 4 pompa dan dilakukan percobaan dengan mengganti nilai kapasitas pompa tersebut antara 0 - 350 liter/menit dan 442.73 liter/menit. Dari hasil percobaan tersebut didapatkan kapasitas pompa yang menghasilkan penurunan muka air tanah yang diinginkan adalah sebesar 246.4 liter/menit. Hasil pemodelan dewatering tersebut dapat dilihat pada gambar berikut ini.
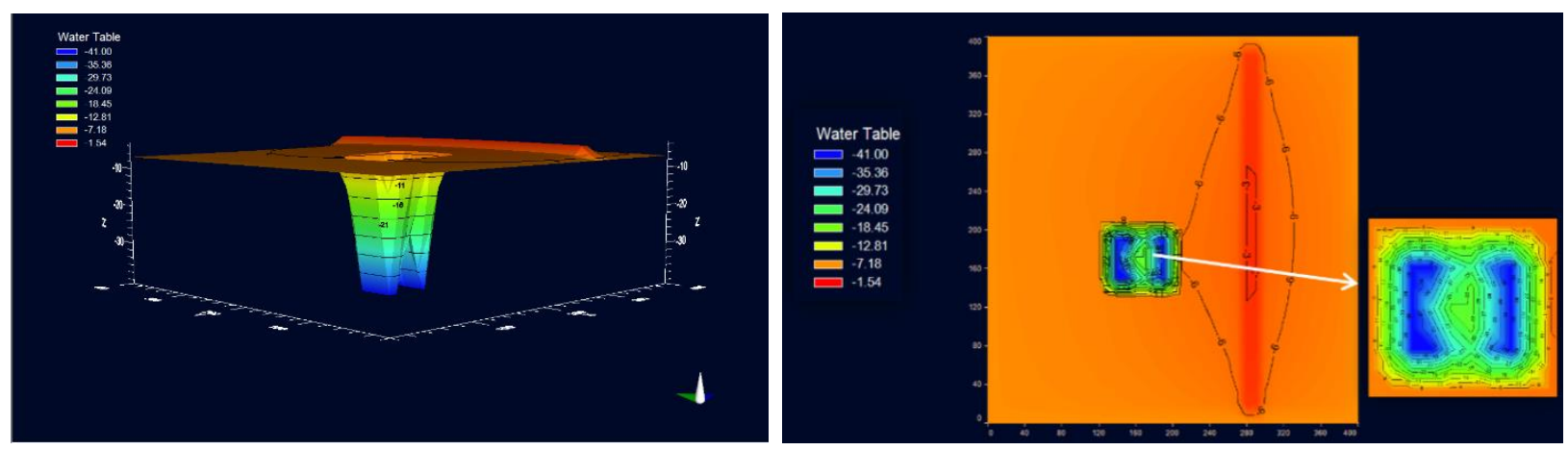

Gambar 8.Tampak atas (kiri) dan tampilan 3D (kanan) pemodelan dewatering (246.4 ltr/mnt)

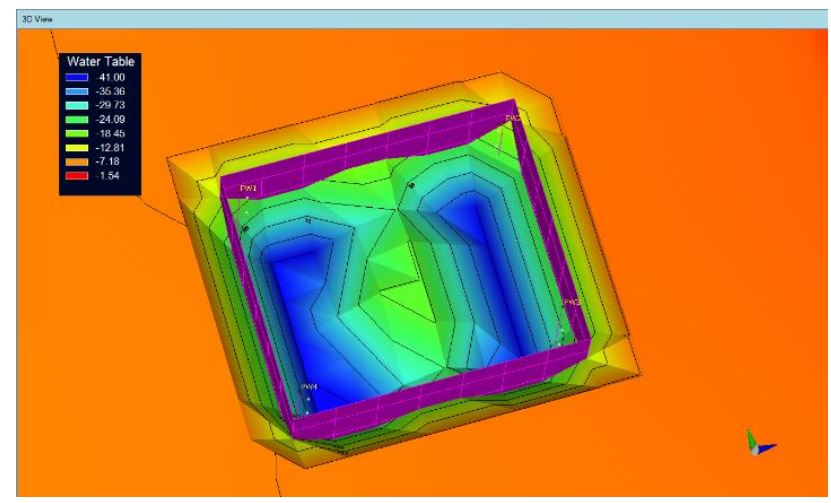

Gambar 9. Tampilan detail 3D pemodelan dewatering (246.4 ltr/mnt)

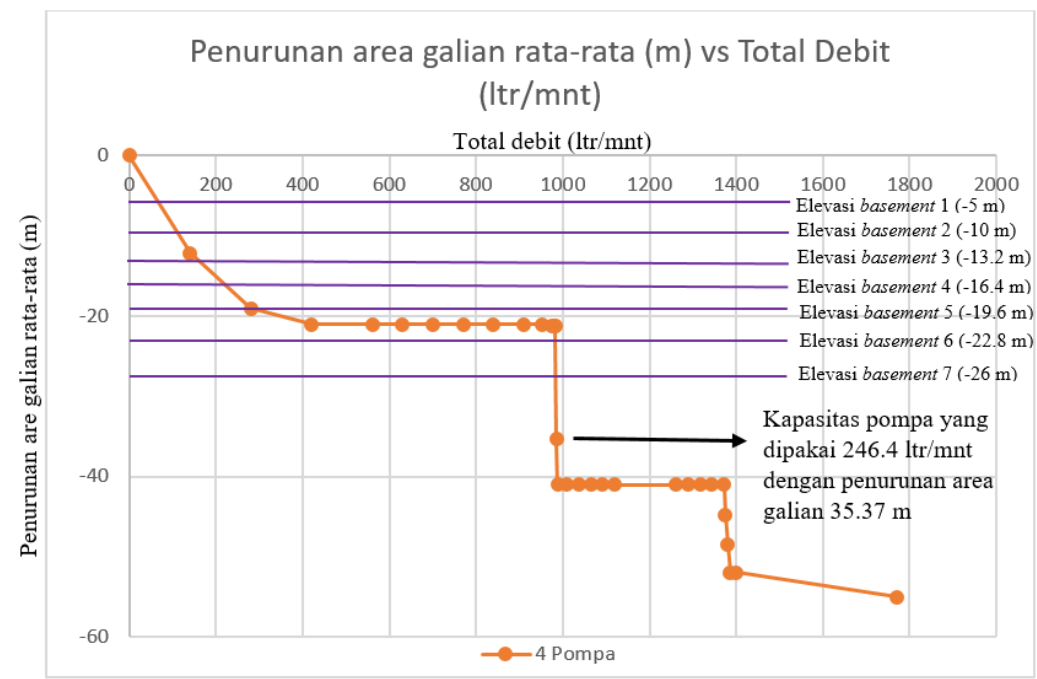

Gambar 10. Hubungan penurunan area galian rata-rata dengan total debit 


\section{Perhitungan dewatering}

Perhitungan dewatering dilakukan hanya sebagai back analysis dari pemodelan dewatering yang sudah dilakukan.

Menentukan jumlah air yang harus dipompa dari seluruh area galian.

$$
r_{s}=\sqrt{\frac{4260}{\pi}}==36.82 \mathrm{~m} \sim 37 \mathrm{~m}
$$

Radius of Influence $\left(R_{o}\right)=237.14 \mathrm{~m}$ (data hasil pumping test)

$$
\begin{aligned}
& Q=\frac{\pi \times 1.17 \times 10^{-4}\left(29.16^{2}-9.06^{2}\right)}{\ln (237.14+37)-\ln (37)} \\
& Q=0.1409 \mathrm{~m}^{3} / \text { detik } \\
& Q=8459.66 \mathrm{liter} / \text { menit }
\end{aligned}
$$

Menentukan kapasitas pemompaan dari setiap well

$$
\begin{aligned}
& Q_{w}=24.91 \times 9.06 \times 202.3 \times \sqrt{1.17 \times 10^{-4}} \\
& Q_{w}=493.84 \text { liter/menit }
\end{aligned}
$$

Jumlah pompa yang diperlukan

$$
\text { Jumlah pompa }=\frac{8459.66}{493.84}=17.13 \sim 18 \text { buah pompa }
$$

Hasil perhitungan dewatering ini merupakan hasil perhitungan tanpa memperhatikan adanya dinding diafragma (diaphragm wall).

\section{KESIMPULAN}

Berdasarkan hasil pemodelan pumping test dengan menggunakan bantuan program berbasis elemen hingga (2D) dan program berbasis beda hingga (3D) dapat disimpulkan beberapa hal seperti berikut.

1. Konduktivitas hidraulik atau permeabilitas merupakan parameter yang mengontrol pola penurunan muka air tanah hasil pumping test. Hal tersebut dapat dilihat pada Gambar 7 bila nilai permeabilitas diubah sesuai hasil perhitungan dengan Thiems's Equilibrium Formula pada kondisi minimum dan maksimum maupun hasil korelasinya dapat menghasilkan pola penurunan muka air tanah yang berbeda.

2. Nilai konduktivitas hidraulik atau permeabilitas pada lapisan aquifer dengan kedalaman 9 - 21 meter yang menggunakan Thiems's Equilibrium Formula adalah berkisar 4.07 hingga $14.92 \mathrm{~m} / \mathrm{hari}$.

3. Diperoleh kecocokan pola penurunan muka air tanah antara pemodelan dengan program dengan hasil uji lapangan pada nilai permeabilitas maksimum dengan rumus Thiem Equilibrium Formula yaitu $14.92 \mathrm{~m} / \mathrm{hari}$.

Sedangkan untuk hasil pemodelan dewatering dengan menggunakan bantuan program berbasis beda hingga (3D) dapat disimpulkan beberapa hal seperti berikut.

1. Pemodelan pumping test dan dewatering dengan pada program berbasis beda hingga (3D) menggunakan pemodelan Numerical Modeling.

2. Jumlah pompa yang dibutuhkan untuk pelaksanaan dewatering pada proyek di Sudirman tersebut adalah 4 buah dengan kapasitas masing-masing pompanya adalah $352 \mathrm{~m}^{3} /$ hari (246.4 liter/menit).

3. Kedalaman yang dicapai pada area galian dengan keempat pompa tersebut adalah sedalam $29.73-41$ meter.

\section{DAFTAR PUSTAKA}

Bowles, J.E. 1996. Foundation Analysis and Design 5th Edition. McGraw-Hill, Singapore

Budhu, Muni dan J.E. Bowles. 2007. Soil Mechanic and Foundation $3^{\text {rd }}$ Edition. John Wiley \& Sons, Inc, America 
Budhu, M. and J.E. Bowles. 2015. Soil Parameters and Correlation. John Wiley \& Sons, New York

Cashman P.M., dan Preene, M. 2013. Groundwater Lowering in Construction A Practical Guide To Dewatering Second Edition. Taylor \& Francis Group, United State of America

Department of the Army, The Navy and The Air Force. 1983. Dewatering and Groundwater Control, NAVY NAVFAC P-418

Kruseman, G.P., dan de Ridder, N.A. 2000. Analysis and Evaluation of Pumping Test Data Second Edition. International Institute for Land Reclamation and Improvement, Netherlands

Powers, J.P., Corwin, A.B., Schmall, P.C., dan Kaeck, W.E. 2007. Construction Dewatering and Groundwater Control New Method and Applications Third Edition. John Wiley \& Sons, United States of America

Thiem, G. 1906. Hydrologische Methoden. Gebhardt, Leipzig

Wesley, L.D. 2010. Mekanika Tanah Untik Tanah Endapan \& Residu. John Wiley \& Sons, Inc, Hoboken 
